\title{
A Revaluation of the Cultural Dimension of Disability Policy in the European Union: The Impact of Digitization and Web Accessibility
}

\author{
Delia Ferri* and G. Anthony Giannoumis ${ }^{\dagger}$
}

Reflecting the commitments undertaken by the EU through the conclusion of the United Nations Convention on the Rights of Persons with Disabilities (UNCRPD), the European Disability Strategy 2010-2020 not only gives a prominent position to accessibility, broadly interpreted, but also suggests an examination of the obligations for access to cultural goods and services. The European Disability Strategy 2010-2020 expressly acknowledges that EU action will support national activities to make sports, leisure, cultural and recreational organizations and activities accessible, and use the possibilities for copyright exceptions in the Directive 2001/29/EC (Infosoc Directive). This article discusses to what extent the EU has realized the principle of accessibility and the right to access cultural goods and services envisaged in the UNCRPD. Previous research has yet to explore how web accessibility and digitization interact with the cultural dimension of disability policy in the European Union. This examination attempts to fill this gap by discussing to what extent the European Union has put this cultural dimension into effect and how web accessibility policies and the digitization of cultural materials influence these efforts. Copyright (C) 2014 John Wiley \& Sons, Ltd.

\section{INTRODUCTION}

International developments, such as the International Year of the Disabled in 1981 and the implementation of the World Programme of Action Concerning Disabled Persons inspired the former European Community (EC), now the European Union (EU), to develop a social policy approach to disability (UN, 1992). This approach links back to the 1986 Recommendation 86/379/EEC on the Employment of Disabled People in the Community, which aimed to promote equal opportunities for people with disabilities (Waddington, 2006).

In 1996, the former EC launched the European Community Disability Strategy, which advocated the identification and removal of barriers preventing individuals with disabilities from achieving equality of opportunity and full participation in all aspects of social life (Hosking, 2013; Mabbett, 2005; Muñoz Machado \& Lorenzo, 1997; Waddington, 1999, 2006). The 1996 strategy represented the cornerstone for the development of a more robust disability policy, first through the EU Disability Action Plan for the years 2004-2010, and, then through the European Disability Strategy 2010-2020.

\footnotetext{
*Correspondence to: Delia Ferri, Centre of Disability Law and Policy, National University of Ireland, Galway. E-mail: Delia.ferri@nuigalway.ie

${ }^{\dagger}$ Centre for Welfare and Labour Research at the Oslo and Akershus University College of Applied Sciences
} 
The European Disability Strategy 2010-2020, adopted in November 2010, sets forth the current policy framework (Hosking, 2013), and attempts to mainstream disability in all EU policy fields to ensure that people with disabilities enjoy their full rights. While the previous policy programs had (mainly, though not exclusively) a strong focus on employment and accessibility in relation to transportation and the built environment, the European Disability Strategy 2010-2020 adopts a wider approach articulated by eight interconnected areas of action: accessibility, participation, equality, employment, education and training, social protection, health and external action.

The structure and content of the European Disability Strategy 2010-2020 have been greatly influenced by the EU's negotiation, signing and accession to the UN Convention on the Rights of Persons with Disabilities (UNCRPD). The EU signed the UNCRPD on March 2007 and, along with several Member States, concluded the UNCRPD with the Council decision of 26 November 2009. The UNCRPD currently enjoys a quasi-constitutional status in the EU legal system, beneath treaties but above secondary law (Ferri, 2009, forthcoming 2013). The EU must implement the UNCRPD and put its provisions into effect, at least within the sphere of EU competence. In addition, EU institutions must consider the EU's international obligations when interpreting EU secondary law.

Rather than creating new rights for disabled persons (Quinn, 2009a, 2009b), the UNCRPD elaborates and clarifies existing human rights within the social context of disability (Anderson \& Philips, 2012; Kayess \& French, 2008; Seatzu, 2008). The innovative drafters of the UNCRPD fully recognized the inherent dignity and diversity of people with disabilities, and aimed to ensure the active participation of persons with disabilities in political, economic, social, and cultural life. The UNCRPD acknowledges that protection against discrimination and the promotion of autonomy and legal capacity alone do not accommodate the differences of people with disabilities. Hence, the UNCRPD lays down the principle of accessibility and broadly defines this principle to include physical accessibility, economic accessibility (i.e., affordability) and information accessibility (Halvorsen, 2009). The UNCRPD additionally provides for different rights of access and participation (Lord, 2010; Quinn, 2009b), including access to information and culture. In these provisions, the UNCRPD promotes the role of accessible technology and digitization.

Reflecting the commitments undertaken by the EU through the conclusion of the UNCRPD, the European Disability Strategy 2010-2020 not only gives a prominent position to accessibility, broadly interpreted, but also suggests an examination of the obligations for access to cultural goods and services. The European Disability Strategy 2010-2020 expressly acknowledges that EU action will support national activities to make sports, leisure, cultural and recreational organizations and activities accessible, and use the possibilities for exceptions in the Directive 2001/29/EC. This statement, in conjunction with the second work plan, adopted under the European Agenda for Culture, sets out the EU-level activities that target the field of culture during the period 2011-2014. This plan, though not explicitly mentioning disability, specifies priority areas, including accessible and inclusive culture. More recently, the Council Conclusions of the 164th Education, Youth, Culture, and Sport Council meeting, held in Brussels in May 2012, stated that:

the digitisation and online accessibility of the Member States' cultural material and its longterm digital preservation are essential to enable access for all [emphasis added] to culture and 
knowledge in the digital era and to promote the richness and diversity of European cultural heritage (Council of the European Union, 2012). ${ }^{1}$

In addition, a general commitment towards the promotion of ICT and accessible formats emerges from Europe 2020, which to some extent complements the European Disability Strategy 2010-2020 and the Digital Agenda.

The European Disability Strategy 2010-2020 does not mention culture as a key theme or autonomous area of action. However, the European Disability Strategy 2010-2020 explicitly introduces the cultural dimension of disability policy, which was substantially ignored by the previous EU Disability Action Plan 2004-2010. Whether and how the EU realizes this cultural dimension remains unclear. Previous research has yet to explore how web accessibility and digitization interact with the cultural dimension of disability policy in the EU.

This article attempts to fill this gap by discussing to what extent the EU, further to the accession to the UNCRPD, has put this cultural dimension into effect. It discusses how accessibility requirements and the digitization of cultural materials influence these efforts, and examines the perspectives opened up by the UNCRPD at the EU level. This article pays particular attention to EU copyright law. The analysis aims to demonstrate that the EU made active attempts to realize the principle of accessibility and the right to access cultural goods and services enshrined in the UNCRPD.

The article begins with an overview of the cultural rights provided for in the UNCRPD. It does not aim to provide a comprehensive outline of the UNCRPD (Harnacke \& Graumann, 2012), but instead focuses on those aspects that relate to the present analysis. The article continues by exploring the meaning of accessibility requirements for cultural goods and services. Then, we offer a brief outline of EU powers and a critical summary of how EU policies realize the principle of accessibility and right to access cultural goods embedded in the UNCRPD. The article continues by exploring how accessibility requirements imposed by the UNCRPD and trends toward digitization promote a revaluation of EU copyright law and interact with international copyright law. We conclude by summarizing these arguments.

\section{CULTURAL RIGHTS IN THE UNCRPD: RECOGNIZING ACCESS AND PARTICIPATION}

Traditionally, both national and international norms explained the disadvantageous situation of disabled people by focusing on physical and mental impairments, rather than understanding disability as the result of discrimination and the inadequate realization of rights. By contrast, the UNCRPD embodies the official recognition of disability as a human rights issue, and affirms the social model (Harpur, 2012; Stein \& Lord, 2009) as opposed to the medical model of disability (Barnes, 2009; Barton, 1996; Burchardt, 2004; Oliver, 1996; Traustadottir, 2009). The 25 paragraphs of the preamble and $50 \mathrm{Ar}-$ ticles of the UNCRPD reflect the reality that disability originates primarily from the failure of the social environment to meet the needs and aspirations of people with impairments.

The extremely broad scope of the UNCRPD does not simply prohibit disability discrimination, but includes civil, political, economic, cultural and social rights founded

\footnotetext{
1 http://www.consilium.europa.eu/uedocs/cms_data/docs/pressdata/en/educ/130120.pdf (accessed January 2014).
} 
on the core and manifold concepts of personal dignity, autonomy, and self-determination. The UNCRPD includes an introductory set of provisions outlining its purpose and key definitions (Articles 1-2). Articles 3-9 of the UNCRPD set out general provisions for the treaty text. Article 4 of the UNCRPD requires Parties:

to take measures to abolish disability discrimination; to engage in the research and development of accessible goods, services and technology for persons with disabilities and to encourage others to undertake such research; to provide accessible information about assistive technology to persons with disabilities; to promote professional and staff training on the Convention rights for those working with persons with disabilities; and to consult with and involve persons with disabilities in developing and implementing legislation and policies and in decision-making processes concerning the UNCRPD rights.

Significantly, Article 4 further requires Parties to adopt an inclusive policy approach to protect and promote the rights of persons with disabilities in all laws and programs. Article 4 furthers the need to assess inclusion in programs, policies, and laws across all sectors pursuant to the obligations of the UNCRPD. Article 4 suggests that the concept of "mainstreaming" (i.e., including disability perspectives in policy formation) obliges States to "re-think" disability policymaking.

The UNCRPD establishes accessibility as one of its core principles and acknowledges accessibility as a precondition for independent life and full and equal participation of persons with disabilities in society. Article 9 of the UNCRPD demonstrates that, to enable persons with disabilities to live independently and participate fully in all aspects of life, States Parties must take appropriate measures to ensure access for persons with disabilities to the physical environment, transportation, information and communications (including the Internet), and other facilities and services open or provided to the public. The Draft General Comment on Article 9 of the Convention, published by the Committee on the Rights of Persons with Disabilities (the UN monitoring body for the UNCRPD), affirms the inherent complexity of accessibility, and specifies that denial of access should be considered a discriminatory act (UN Committee on the Rights of Persons with Disabilities, 2013).

Articles 10-30 enumerate the specific substantive rights, which form the obligations for States Parties. Article 30 ensures participation in cultural life, sports, and recreation. Therefore, access to information and to cultural goods and services maintains a prominent position in the UNCRPD, which acknowledges the importance of cultural rights as mechanisms for realizing participation and ultimately social inclusion (Quinn, 2009a; Stamatopoulou, 2007; UNESCO, 2002). Cultural rights refer to a category of human rights, alongside civic, political and economic, and social rights, including both individual and collective rights, related to cultural, language or national minorities and to artistic, expressive and intellectual forms of creation. Article 5 of the UNESCO Declaration on Cultural Diversity clarifies the concept of cultural rights, stating that "Cultural rights are an integral part of human rights, which are universal, indivisible and interdependent" (UNESCO, 2002). The flourishing of creative diversity requires the full implementation of cultural rights as defined in Article 27 of the Universal Declaration of Human Rights and in Articles 13 and 15 of the International Covenant on Economic, Social and Cultural Rights (UN, 1967, 1988).

Article 21 of the UNCRPD requires States Parties to provide information intended for the general public to persons with disabilities in accessible formats and technologies; to accept and facilitate the use of sign languages, Braille, and all other accessible 
formats of communication; to encourage the mass media to make their services accessible to persons with disabilities; and to recognize and promote the use of sign languages. While traditionally freedom of expression has been constructed as a negative right, where the State only has to secure that no one interferes with the freedom of opinion and expression of its citizens, the UNCRPD turns this negative right into a positive one (Harnacke \& Graumann, 2012; Koch, 2009)

Analogously, Article 30 of the UNCRPD, which provides the right for persons with disabilities to participate in cultural life, requires States Parties to take all appropriate measures to ensure that persons with disabilities have access to cultural materials, television programs, films, theatre and other cultural activities, and to places for cultural performances or services, monuments and sites (Laaksonen, 2010). The Draft General Comment on Article 9 of the Convention emphasizes the importance of this obligation, and states:

[e]veryone has the right to enjoy arts. [...] But a wheelchair user cannot go to a concert if there are only stairs in the concert hall. A blind person cannot enjoy a painting if there is no description of it he can hear in the gallery. A deaf person cannot enjoy a movie if there are no subtitles. A person with intellectual disability cannot enjoy a book if there is no easy- to- read version of it.

Overall, this provision clearly aims to increase the low participation rate of people with disabilities as arts practitioners and end users of cultural goods and services. To this purpose, the Draft General Comment establishes that Parties to the UNCRPD must ensure that laws protecting intellectual property rights do not constitute an unreasonable or discriminatory barrier to accessing cultural materials. This provision relates primarily to copyright issues with respect to electronic versions of documents for blind users and captioning of audio tracks for deaf users (Brown, Harmon, \& Waelde, 2012; Rekas, 2013). Captions refer to on-screen text descriptions that display a video product's dialogue, identify speakers, and describe other relevant sounds that otherwise constitute inaccessible content for deaf or hard-of-hearing persons. Captioning allows a person with a hearing impairment to have access to the audio track of an audio-visual work by displaying the audible content as text on the screen. The international WIPO Copyright Treaty to facilitate access to published works, adopted in June 2013, should ensure the access to cultural material without unreasonable or discriminatory barriers for persons with disabilities, especially those persons facing challenges accessing print materials (WIPO, 2013).

The 1993 Standard Rules on the Equalization of Opportunities for Persons with Disabilities recognized the importance of access to information and communication, and contained a specific rule on culture (Rule 10). This Rule specified that States should ensure the integration and participation of persons with disabilities in cultural activities on an equal basis, and that persons with disabilities have the opportunity to utilize their creative, artistic and intellectual potential. The Standard Rules also provide that States should promote accessibility to and availability of places for cultural performances and services, and initiate the development and use of special technical arrangements to make literature, films and theatre accessible to persons with disabilities. As the web continues to disrupt the forprofit and non-profit industries that produce these cultural products, the impact of inaccessible web content produces new and more entrenched barriers. The Standard Rules established a shift in the approach of international instruments towards disability (Michailakis, 1999); however, as a soft law document, the Standard Rules maintained 
no obligations for States Parties. In addition, the authors of the Standard Rules drafted Rule 10 broadly, not explicitly mentioning intellectual property rights.

In other binding legal instruments, formulation of cultural rights did not include a reference to disability. The International Covenant on Economic, Social and Cultural rights (ICESCR) defines cultural rights broadly (Article 15). The General Comment 5 of the Committee on Economic, Social and Cultural Rights affirmed that States Parties should interpret and implement the ICESCR with regard to persons with disabilities in light of the 1993 Standard Rules (UN, 1967, 1995). The most recent General comment no. 21, Right of everyone to take part in cultural life refers to Article 30 of the UNCRPD. The latter document also refers to accessibility and states:

effective and concrete opportunities for individuals and communities to enjoy culture fully, within physical and financial reach for all in both urban and rural areas, without discrimination. It is essential, in this regard, that access for older persons and persons with disabilities, as well as for those who live in poverty, is provided and facilitated. Accessibility also includes the right of everyone to seek, receive and share information on all manifestations of culture in the language of the person's choice, and the access of communities to means of expressions and dissemination.

Although not primarily intended to promote and protect cultural rights, the UNESCO Convention on the Protection and Promotion of the Diversity of Cultural Expressions touches upon, and to some extent incorporates, these rights. However, the UNESCO convention does not explicitly mention disability (Aylett, 2010; Cornu, 2006; Donders, 2010; Pineschi, 2008; UNESCO, 2005). The main international organization dealing with culture, UNESCO, has undertaken several studies and initiatives on human rights and disability (Beiter, 2006; Degener, 1995), but these efforts focused on education rather than access to cultural goods and services or cultural participation (UNESCO, 2006).

Finally, Article 30 of the UNCRPD has also provided an important symbolic value by ending the marginal status of arts and culture for people with disabilities and stimulating the debate on the access to cultural goods for people with disabilities (Moreno, Galvez, Ruiz, \& Martinez, 2008). The publication of a monograph on access to museums in a recent volume of Disability Studies Quarterly provides the best and the latest (but not the last) evidence of this debate (Disability Studies Quarterly, 2013).

\section{ACCESSIBILITY REQUIREMENTS FOR CULTURAL MATERIALS AND THE ROLE OF DIGITIZATION}

Regulations adopted by supranational, national, and regional governments recognize the importance of introducing accessibility requirements and regulating web content to provide social inclusion and equal opportunities for persons with disabilities ("Accessibility for Ontarians with Disabilities Act," 2005; Australia Human Rights and Equal Opportunity Commission, 2002; Department of Justice, 2012; EC, 2011; ictQatar, 2011; New Zealand Government Web Toolkit, 2013; UN, 2007). Policy actors have additionally attempted to stimulate discourse on the financial benefits of web accessibility and digitization. Digitization (i.e., the conversion of non-digital works into formats for use on computers) provides an effective means to reproduce and 
distribute cultural materials in accessible formats for use by persons with disabilities. Libraries and other predominantly non-profit efforts have led digitization efforts. Despite these efforts, cultural content published on the web remains widely inaccessible for persons with disabilities (Blanck, 2015, in press; Easton, 2011, 2012, 2013a,2013b; Kuzma, 2010; Ritchie \& Blanck, 2003; Sandler \& Blanck, 2005).

In particular, compliance with intellectual property rights (namely copyright) has challenged these efforts. Copyright refers to a temporary exclusive right over the expression of an idea and arises automatically and without formality upon creation of the work, once that work exists in some material, reproducible form (Cook, 2010; Lewinski, 2008). Having identified property rights and negotiated licenses, digitization must preserve the rights of copyright holders by taking steps to ensure that no unauthorized use of materials occurs. The Creative Commons initiative has released of a set of copyright licenses available free for public use, and enables individuals to share and dedicate creative works to the public domain or retain copyright while licensing the work as free for certain uses and on certain conditions.

Since the 1990s, the production and consumption of cultural products have transitioned to the web. Prior to the web, public and private sector actors monopolized the channels that content creators (i.e., copyright holders) used to distribute cultural products. The availability of the web has equalized the ability to produce and distribute cultural products among previously established content producers, market entrants and the broader public. The ability to produce cultural products has diffused across boundaries created by previously established service providers. This equalization produced unprecedented growth in the amount and types of cultural products that individuals, groups, and organizations have produced. However, while the web as an information resource remains largely inaccessible to persons with disabilities, inaccessible web content creates an additional barrier to the communication potential of the web (Blanck, 2014, this issue). This prevents persons with disabilities from creating and distributing cultural products via the web.

These trends forced established content producers to adapt content for distribution over the web, adopt new business practices to simultaneously ensure the continued viability of established business models and create new business models to attempt to compete on the web (IDATE, 2012). However, this transition has generated inequalities in how users generate and consume these products. Although copyright law intends to protect the rights of content creators and encourage the production of cultural products, these laws have not adjusted to the introduction of the web (Hargreaves, 2011b; Hargreaves \& Hugenholtz, 2013). Contrarily, copyright laws have preserved a business model that continues to discriminate against persons with disabilities (LIBER, 2013; Summer, 2011).

This business model has generated a social movement that relies on illegally copied and distributed cultural products to satisfy market demand. As these infringing efforts continue, content producers have begun to condone copyright infringement as part of the distribution of cultural products in the information society and acknowledge infringement as an indicator of successful distribution (Sar, 2013a,2013b; Thielman, 2013). The result of this business model, which fails to respond to the demands of consumers, further contributes to barriers for persons with disabilities. National and supranational regulators continue to struggle to influence web content accessibility and the legal creation and distribution of cultural products through copyright law. As the copyright infringement of cultural products continues to provide a socially and economically legitimate, though illegal, mechanism for social participation, copyright 
law that allows these business models to persist also contributes to further barriers to achieving web accessibility.

\section{DISABILITY AND CULTURE IN THE EU: A "NET" OF CROSS-CUTTING COMPETENCES}

Having explored the content of the obligations laid down in Articles 9, 21 and 30 UNCRPD, and having illustrated the role of accessibility requirements and digitization, we now briefly outline the set of different EU shared and supporting competences involved in implementing cultural rights of people with disabilities.

The values of equality and respect for fundamental rights form the foundation of the EU. The EU has made a commitment to endorse the values of respect for freedom, pluralism and non-discrimination, and cultural diversity, which originate with the EU treaties and the Charter of Fundamental Rights of the European Union (EUCFR). Article 21 of the EUCFR prohibits discrimination on the grounds of disability, and Article 26 of the EUCFR supplements this provision, stating, "the Union recognises and respects the right of persons with disabilities to benefit from measures designed to ensure their independence, social and occupational integration and participation in the life of the community."

The competence to take action to address disability discrimination originates with Article 19 of the Treaty on the Functioning of the European Union (Article 19 TFEU), which allows the EU to enact measures to combat discrimination on the grounds of disability. In addition, Article 10 TFEU imposes a mainstreaming duty in relation to all the grounds of discrimination prohibited under EU law.

Member States still retain and exercise full competence in the cultural domain (which remains a politically sensitive area), but Article 3 of the Treaty on the European Union (TEU) provides that the EU shall respect Europe's rich cultural and linguistic diversity, and shall ensure the safeguarding and enhancement of Europe's cultural heritage (EU, 2008). To this purpose, the EU can carry out actions to support, coordinate or supplement national actions. Article 167(5) TFEU clarifies that the EU, through legislative procedures, can adopt incentive measures, excluding any harmonization (EU, 2008). In addition, Article 167(4) TFEU establishes that the EU must take cultural aspects into account in actions under other provisions of the Treaty, in particular to respect and to promote the diversity of its cultures.

Article 167(4) TFEU states that EU cultural policy inherently interacts with other areas of EU competence. However, Member States cannot use Article 167 TFEU to justify national measures that may hinder intra-EU trade (Article 36 TFEU) (Case C-531/07 Fachverband der Buch- und Medienwirtschaft v. LIBRO). In this respect, Article 107 TFEU leaves to the Commission the possibility to declare State aid that promotes culture compatible with the internal market (EU, 2008; Zagato, 2010). Thus, European rules on the internal market and competition directly and indirectly impact the cultural and creative sectors (Cortese, 2011; Ferri, 2008; Psychogiopoulou, 2008; Smith, 2011b). Particularly relevant, Article 114 TFEU states that the EU can adopt measures that aim to support the internal market. The EU has used this provision as the legal basis of a number of legislative acts on audio-visual communication and telecommunication (Ferri, 2008). 
The Treaty of Lisbon has conferred on the EU new and considerable powers to establish measures for the creation of European intellectual property rights to provide uniform protection of intellectual property rights throughout the EU and for the setting up of centralized EU-wide authorization, coordination and supervision arrangements (Article 118 TFEU) (EU, 2008). However, the powers of the EU remain (in principle) limited. Article 345 TFEU reproduces former Article $295 \mathrm{EC}$ and affirms the principle of non-interference in the property regimes of the Member States. The primary purpose of this provision concerned the prerogative of Member States to choose nationalized industries and property over private property. Nevertheless, the provision implicitly accepts the power to grant private property rights, including intellectual property rights.

The implementation of Articles 21 and 30 UNCRPD represent an opportunity to fulfill the mainstreaming duty laid down in Article 10 TFEU. The implementation creates an additional opportunity for the EU to exercise its limited powers in the cultural field, to exploit the full potential of the free movement and internal market rules, to enhance the production and circulation of accessible cultural goods and services, and to take action in the field of intellectual property rights.

\section{THE CULTURAL DIMENSION OF EU DISABILITY POLICY: MAINSTREAMING ACCESSIBILITY "REQUIREMENTS"?}

The EU has realized the cultural dimension of disability policy primarily (though not exclusively) by mainstreaming accessibility "clauses" in legislation (in particular those enacted based on Article 114 TFEU), and financing digitization through cultural programs based on Article 167 TFEU.

The Telecommunications Package aims to ensure fair competition between the telecommunications operators and to increase interoperability and access of EU citizens to ICT by creating a common set of regulations for national industries. The EU amended the Telecommunications Package in 2009, contiguous with the negotiation and conclusion of the UNCRPD. As an internal market measure, the Telecommunications Package does not comprise cultural legislation. Nevertheless, the Telecommunications Package creates the precondition for people with disabilities to exercise their freedom of expression and access to cultural contents. Within the Telecommunications Package, Directive 2002/21/EC on electronic communications networks, as amended, establishes a harmonized framework for the regulation of electronic communications services, electronic communications networks, and associated facilities and services, and contains explicit reference to disability. The EU has extended the scope of this directive to certain aspects of terminal equipment to facilitate access for disabled end-users. Article 8(2) establishes that the national regulatory authorities shall promote competition in the provision of electronic communications networks, electronic communications services and associated facilities and services by ensuring that users, including disabled users, elderly users, and users with special social needs, derive maximum benefit in terms of choice, price, and quality.

Directive 1999/5/EC on radio and telecommunication terminal equipment (R\&TTE Directive) acknowledges the rights of people with disabilities and establishes a regulatory framework for the free movement in the EU of radio equipment and telecommunications terminal equipment. Recital 15 states that, 
telecommunications are important to the well-being and employment of people with disabilities who represent a substantial and growing proportion of the population of Europe, and that [...] radio equipment and telecommunications terminal equipment should therefore in appropriate cases be designed in such a way that disabled people may use it without or with only minimal adaptation.

Directive 2010/13/EU on Audiovisual Media Services (AVMSD) amends and renames the Television without Frontiers Directive (Directive 89/552/EEC, as amended by subsequent acts) and lays down a legal framework relevant for the implementation of Article 30 UNCRPD. The AVMSD governs EU-wide coordination of national legislation on all audio-visual media, both traditional TV broadcasts and ondemand services, and recognizes that audio-visual media services constitute both cultural and economic services (Smith, 2011a). The Directive obliges Member States to ensure that audio-visual commercial communications shall not include or promote any discrimination based on sex, racial or ethnic origin, nationality, religion or belief, disability, age or sexual orientation. However, most significantly for the purpose of the present analysis, the Directive includes a provision on accessibility for people with disabilities. According to Article 7 AVMSD, Member States shall encourage media service providers under their jurisdiction to ensure the gradual realization of accessibile media services for people with a visual or hearing disability. This provision means that national governments must encourage media companies under their jurisdiction to use sign language, subtitling, audio-description or easily understandable menu navigation. This requirement provides more of a programmatic than a prescriptive regulation. The EU's negotiation and accession to the UNCRPD have influenced the text of the AVMSD. Taking into account the limited EU competence in the cultural field, the AVMSD may not fully comply with the obligations laid down in Articles 21 and 30 UNCRPD.

With regard to EU historical documents, even prior to the accession to the UNCRPD, the Regulation (EC, Euratom) No. 1700/2003, which amended Regulation (EEC, Euratom) No. 354/83, concerning the opening to the public of the historical archives of the EEC and the Euratom, introduced a provision stating that each institution must conserve documents made available in forms meeting special needs (Braille, large text or recordings). The EU recently proposed an amendment to this regulation that provides for the depositing of the historical archives of EU institutions at the European University Institute (EUI) in Florence, and requires that "[e] ach institution shall adopt internal rules for the application of this Regulation." This adoption procedure shall include rules for the preservation, publication and protection of personal data contained in the historical archives. Wherever possible, the institutions shall make the archives available to the public by electronic means. The institutions shall also conserve documents made available in forms meeting special needs (Braille, large text or recordings). Both the Regulation (EC, Euratom) No. 1700/2003 and the proposed amendment comply with Articles 21 and 30 UNCRPD. Nevertheless, this provision may not fulfill the obligation laid down in Article 30 UNCRPD if these institutions pursue digitization and web publication without ensuring accessibility.

After the accession to the UNCRPD, the EU has put the cultural dimension of disability policy into further effect through the EU's Culture program (2007-2013). Although the Decision 1855/2006/EC adopting the program does not mention disability or access to culture for people with disabilities, this program funded several projects involving people with disabilities and accessibility since 2009. A 3-year project on 
accessibility, which included practical demonstrations of new policies and techniques, promoted accessibility in the heritage field (DG Education and Culture, 2009). Creative Europe 2014-2020 finances projects and activities enhancing digitization and access to cultural materials for people with disabilities (DG for Internal Policies of the Union, Mercer, Obuljen, Primorac, \& Uzelac, 2012). The program puts emphasis on the digital shift, though regrettably it does not mention disability, disabled users or practitioners (DG for Internal Policies of the Union et al., 2012). National digitization projects, to which EU funding has contributed, have also increased the accessibility of museums and cultural heritage. ${ }^{2}$ Creative Europe 2014-2020 offers support to continue strengthening and spreading these experiences.

The EU considers digitization and online accessibility of cultural materials essential to highlight cultural and scientific heritage, to inspire the creation of new content, and to encourage new services. Thus, the EU created Europeana, ${ }^{3}$ a portal that brings together digitized content from Europe's museums, archives, libraries and audio-visual collections. While not a disability-specific initiative, Europeana may prove indispensable for allowing people with disability to access cultural products.

\section{Promoting Access to Cultural Goods and Services through Copyright Exceptions within the EU}

The promotion and the actual enforcement of copyright exceptions provided by EU legislation should foster access to cultural goods, in particular to books and printed materials for the visually impaired and print disabled.

Presently, the EU has engaged in significant harmonization of the many aspects of copyright law to reduce barriers to trade and to adjust the framework to new forms of exploitation. However, the EU does not have a fully harmonized copyright regime. Generally speaking, national law still governs copyright, though these laws must comply with international and EU law (Rekas, 2013).

Without exploring the complexity of the copyright rules within the EU, the main EU piece of legislation in force consists of the Directive 2001/29/EC on the Harmonization of Certain Aspects of Copyright and Related Rights in the Information Society (InfoSoc Directive). The Directive transposes into EU law the main international obligations arising from the two treaties on copyright and related rights adopted within the framework of the World Intellectual Property Organisation (WIPO), which concern reproduction, communication, and distribution rights.

The Infosoc Directive harmonizes aspects of the law on copyright to ensure competition in the internal market. According to this Directive, Member States must provide for the exclusive right to authorize and prohibit direct or indirect, temporary or permanent reproduction by any means and in any form, in whole or in part for authors, of the original and copies of their works; for performers, of fixations of their performances; for phonogram producers, of their phonograms; for the producers of the first fixation of films, in respect of the original and copies of their films; for broadcasting organizations, of fixations of their broadcasts. Member States must also provide authors, performers, phonogram producers, broadcasting organizations, and producers with the exclusive

\footnotetext{
2 See, for example, the Swedish project to increase accessibility of natural parks and heritage (at http://www. naturvardsverket.se/Documents/publikationer6400/978-91-620-6562-1.pdf).

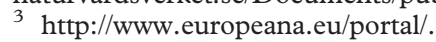


right to authorize or prohibit any communication to the public of copies of their works. In addition, the Directive harmonizes for authors the exclusive right of distribution to the public. In compliance with long-standing and well-established case law of the Court of Justice of the European Union, this distribution right is exhausted where the first sale or first other transfer of ownership is made by the rights holder or with his consent within the EU (Case C-78/70 Deutsche Grammophon v Metro). ${ }^{4}$

The Directive introduces a mandatory exception to the right of reproduction in respect of certain temporary acts of reproduction. The Directive also provides for other non-mandatory exceptions to the rights of reproduction (which includes digitization) or communication. Member States concerned with this provision render the obligations nationally. Among these exceptions, one directly relates to people with disabilities. The Preamble of the Directive makes clear that Member States should be given the option to provide certain exceptions or limitations for use by persons with disabilities. In addition, the Directive clarifies that Member States should adopt all necessary measures to facilitate access to works by persons with disabilities, which may constitute an obstacle to the use of the works themselves, and to pay particular attention to accessible formats.

Notably, Article 5 (3) states that Member States may impose exceptions and limitations to reproduction rights, the right to communicate works to the public and the right to make available to the public other subject matter, for the benefit of persons with disabilities. These exceptions must directly relate to the disability to the extent required by the specific disability and ensure that reproduction constitutes a non-commercial effort. Only special cases, which do not conflict with a normal exploitation of the work and do not unreasonably prejudice the legitimate interests of the rights holder, may apply for this exception. Thus, the Member States may choose to interpret the Directive broadly and, due to the limited scope of the exception, these Member State interpretations may conflict with Article 30 of the UNCRPD.

However, since 2008, the European Commission continues to advance copyright law and aims to finalize a review of the EU copyright framework to address the issue of limitations and exceptions to copyright in the digital age. In 2008, the Commission launched a public consultation on the Green Paper, Copyright in the Knowledge Economy, to examine how a broad dissemination of knowledge in the Single Market, notably in the online environment, could be achieved in the context of existing copyright legislation. In 2009, the Commission published the Communication on Copyright in the Knowledge Economy, which while referring to the outcome of the consultation, announced a series of preparatory actions. Significantly, the communication devotes one section to copyright exceptions for the benefit of persons with disabilities. The Commission recognized that specialist agencies, funded through charities or public subsidies and working under copyright exceptions, provide $95 \%$ of books in accessible formats. In addition, although all the Member States have implemented copyright exceptions, the Member States have not adopted a harmonized approach and the territorial limitation of exceptions hinders the cross-border transfer of the

\footnotetext{
4 If a right related to copyright is relied upon to prevent the marketing in a Member State of products distributed by the holder of the right or with his consent on the territory of another Member State on the sole ground that such distribution did not take place on the national territory, such a prohibition, which would legitimize the isolation of national markets, would be repugnant to the essential purpose of the Treaty, which is to unite national markets into a single market.
} 
material. Explicitly referring to the UNCRPD, the Commission acknowledged that, while the Commission's proposal for a Council Directive on implementing the principle of equal treatment between persons irrespective of religion, belief, disability, age or sexual orientation includes a general principle of equal treatment and accessibility, access to cultural materials requires specific measures.

While persons with disabilities have advocated an EU-wide standardized and comprehensive mandatory copyright exception, publishers want to improve existing voluntary licensing schemes. The Commission has committed itself to encourage publishers to make more works in accessible formats available to disabled persons, and to organize a stakeholder forum concerning the needs of disabled persons, in particular visually impaired persons, and to consider further the possibility of modifying legislation.

The stakeholder's dialogue led to a Memorandum of Understanding (MoU) on access to works by people with print disabilities to increase the number of works published in special formats and facilitate their distribution across the EU. The MoU relies upon the voluntary commitment of publishers to produce accessible content. The stakeholders have also envisaged a network of trusted intermediaries in EU Member States and the creation of an online European accessible e-books service. Subsequently, the European Network of Trusted Intermediaries (ETIN), established at the end of 2012, represents both trusted intermediary organizations and rights holders. Up to now, the ETIN has agreed to a model license agreement for the cross-border transmission of accessible copies of works, and plans to finalize terms for the mutual recognition of Trusted Intermediaries within the ETIN. Both the stakeholders and the Commission recognized that the MoU was only a first step in ensuring general access to all print material to people with visual and print disabilities.

The review of the Digital Agenda, published in December 2012, identifies the need to update the EU's Copyright Framework. Thus, the Commission may choose to review Article 5(3) of the Infosoc Directive.

\section{Promoting Access To Cultural Goods Through The Digitization Of Orphan Works Within The EU}

Another relevant and recent piece of legislation, the Directive 2012/28/EU, sets out common rules on the digitization and online publication of "orphan works" (Gompel \& Hugenholtz, 2010).

As mentioned earlier, the rights holders' exclusive rights of reproduction (harmonized under Directive 2001/29/EC) necessitate the prior consent of rights holders to digitize and publish a work. In the case of orphan works (i.e., books, newspaper and magazine articles, and films still protected by copyright but whose authors or other rights holders are not known or cannot be located or contacted), it is impossible to obtain prior consent. These orphan works raise particular difficulties in the context of mass digitization. Libraries and archives seeking to digitize collections cannot act where rights holders cannot be found for some of the works. Thus, because of the resulting copyright infringement, these organizations must neglect the digitization of those works (Hargreaves, 2011a).

\footnotetext{
5 It address a problem largely analyzed by doctrine; see, inter alia, http://741513.websites.xs4all.nl/ publicaties/vangompel/IIC_2007_6_orphan_works.pdf
} 
The new Directive provides that a work or phonogram declared orphan in a Member State shall be considered an orphan work in all Member States and that libraries, archives, film heritage institutions, public broadcasters, and other organizations acting in the public interest may use and access the work.

While the Directive is a useful tool to spread circulation of cultural material, it will not enable large-scale digitization of orphan works by libraries (EIFL, 2013). First, the Directive will have to be implemented by Member States. Secondly, on a more substantive point of view, rights holders may end the orphan work status at any time, and Member States shall provide a fair compensation to any reappearing rights holder. In addition, the Directive provides onerous reporting requirements to substantiate that the search for the rights holder was diligent. Finally, the Directive excludes standalone photographs and images, a significant form of digitized cultural products.

Despite this criticism, while not a disability-specific measure, this Directive might (at least potentially) represent an important step to increase accessibility for people with disabilities. Digitization allows for the adaptation of works and for wider circulation among people with disabilities. This Directive is also a step forward in making online access to cultural content (even if only orphan works) easier, which also potentially benefits people with disabilities and contributes to implementing Article 30 UNCRPD.

\section{Promoting Access to Cultural Goods Worldwide}

The EU has not only promoted access to cultural goods internally, but also has played an important role globally. In particular, the EU has actively participated in negotiations within the WIPO on an international pact to improve access to copyrighted works for visually impaired and people with print disabilities around the world (Kongolo, 2012; Rekas, 2013). During the negotiation, the Commission, on behalf of the EU, tabled a proposal for a Joint Recommendation Concerning the Improved Access to Works Protected by Copyright for Persons with a Print Disability (WIPO, 2010). This non-binding recommendation aimed to encourage Member States to introduce into national copyright law an exception that covers uses directly related to print disability, to the extent required by the specific print disability, and that constitute a non-commercial effort (Rekas, 2013). The Marrakech Treaty, adopted by the WIPO on 27 June 2013, aims to facilitate access to published works for blind, visually impaired, or otherwise print-disabled persons. This treaty creates a mandatory exception to copyright that allows organizations for the blind to produce, distribute and make available accessible copies to visually impaired persons without the authorization of the rights holder. In particular, the Marrakech Treaty requires contracting parties to adopt laws allowing the reproduction and distribution of published works in accessible formats through limitations and exceptions to the rights of copyright holders. The Marrakech Treaty also provides for the exchange of these accessible works across borders by organizations that serve the blind, visually impaired, and print-disabled.

The enthusiasm that surrounded the adoption of the Marrakech Treaty indicates that the EU and Member States may accede to the Treaty. In addition, as a matter of coherence between internal and external EU policies, the EU could also revise Article 5(3) of the Infosoc Directive. 


\section{CONCLUDING REMARKS}

This brief overview has attempted to show that a cultural dimension of disability policy has emerged further to the accession to the UNCRPD and the launch of European Disability Strategy 2010-2020. Through the mainstreaming of accessibility requirements and diffusion of digitization, the EU has "shaped" this dimension and has started to realize the principle of accessibility and the right to access cultural goods and services embedded in the UNCRPD.

Indeed, the EU has only initially approached the implementation of Articles 9, 21, and 30 of the UNCRPD, in the fields falling within its competence. Nevertheless, the area of copyright exceptions and orphan works demonstrates some, though incomplete, progress. In particular, with regard to copyright, the significant efforts displayed at the policy level have not yet led to a change of the Infosoc Directive. However, the envisaged reform of EU copyright legislation cannot but take into account both the UNCRPD and the Marrakesh Treaty, and might finally lead to the reinforcement of the exceptions provided for in Article 5(3).

\section{REFERENCES AND BIBLIOGRAPHY}

Accessibility for Ontarians with Disabilities Act, 2005: statutes of Ontario, 2005, chapter 11: office consolidation [Loi de 2005 sur l'accessibilité pour les personnes handicapées de l'Ontario: lois de l'Ontario de 2005, chapitre 11: codification administrative], Queen's Printer for Ontario (2005).

Anderson, J., \& Philips, J. P. M. (2012). Editor's Introduction. In J. Anderson \& J. P. M. Philips (Eds.), Disability and universal human rights: legal, ethical, and conceptual implications of the Convention on the rights of persons with disabilities. Utrecht: Netherlands Institute of Human Rights.

Australia Human Rights and Equal Opportunity Commission. (2002). World Wide Web access Disability Discrimination Act advisory notes

Aylett, H. (2010). An international instrument for international cultural policy: the challenge of UNESCO's Convention on the protection and promotion of the diversity of cultural expressions 2005. International Fournal of Cultural Studies, 13(4), 355-373. doi: 10.1177/1367877910369975

Barnes, C. M. G. (2009). Exploring disability. Cambridge: Polity.

Barton, L. (1996). Disability and society: emerging issues and insights. London; New York: Longman.

Beiter, K. D. (2006). The protection of the right to education by international law: including a systematic analysis of article 13 of the International Covenant on Economic, Social, and Cultural Rights. Leiden-Boston: Martinus Nijoff.

Blanck, P. (2014) The struggle for web eQuality by persons with cognitive disabilities. Behavioral Sciences and the Law, 32(1). doi: 10.1002/bsl.2101

Blanck, P. (2015). eQuality: Web Rights, Human Flourishing, and Persons with Cognitive Disabilities. New York: Cambridge University Press. In press.

Brown A., Harmon, S. H. E., \& Waelde, C.. (2012). Do you see what I see? Disability, technology, law and the experience of culture. IIC Int. Rev. Intellect. Prop. Compet. Law IIC International Review of Intellectual Property and Competition Law, 43(8), 901-930.

Burchardt, T. (2004). Capabilities and disability: the capabilities framework and the social model of disability. Disability \& Society, 19(7), 735-751.

Cook, T. M. (2010). EU intellectual property law. Oxford; New York: Oxford University Press.

Cornu, M. (2006). The Convention on the Protection and Promotion of the Diversity of Cultural Expressions: new instrument for the international law of culture [La Convention pour la protection et la promotion de la diversité des expressions culturelles: nouvel instrument au service du droit international de la culture]. Fournal of International Law [Fournal du droit international], 1332006, 929-935.

Cortese, B. (2011). Principles of the Internal Market and Europe of Culture [Principi del Mercato Interno ed Europa della Cultura]. In L. Zagato \& M. Vecco (Eds.), The cultures of Europe, the Europe of culture [Le culture dell'Europa, l'Europa della cultura]. Milano, Italy: FrancoAngeli.

Degener, T. (1995). Disabled Persons and Human Rights: the Legal Framework. In T. Degener \& Y. Koster-Dreese (Eds.), Human rights and disabled persons: essays and relevant human rights instruments. Dordrecht; Boston: M. Nijhoff. 
DG Education and Culture. (2009). Culture in Motion.

DG for Internal Policies of the Union, Mercer, C., Obuljen, N., Primorac, J., \& Uzelac, A. (2012). The culture strand of the creative Europe programme 2014-2020. Luxembourg: Publications Office of the European Union.

Disability Studies Quarterly. (2013) Double Issue: Museum Experience and Blindness. The Ohio State University Libraries: Columbus, OH, Vol. 33 (3 ed.).

Donders, Y. (2010). The Cultural Diversity Convention and Cultural Rights: Included or Ignored? In T. Kono \& S. V. Uytsel (Eds.), The UNESCO Convention for the Promotion and Protection of Diversity of Cultural Expressions. Antwerpen [u.a.]: Intersentia.

Easton, C. (2011). The Web Content Accessibility Guidelines 2.0: An Analysis of Industry Self-regulation. International fournal of Law and Information Technology, 19(1), 74-93.

Easton, C. (2012). Revisiting the law on website accessibility in the light of the UK's equality act 2010 and the United Nations convention on the rights of persons with disabilities. International fournal of Law and Information Technology, 20(1), 19-47.

Easton, C. (2013a). An examination of the Internets development as a disabling environment in the context of the social model of disability and anti-discrimination legislation in the UK and USA. Universal Access in the Information Society, 12(1), 105-114.

Easton, C. (2013b). Website accessibility and the European Union: citizenship, procurement and the proposed Accessibility Act. International Review of Law, Computers E Technology, 27(1-2), 187-199.

EIFL. (2013). The European Orphan Works Directive - an EIFL Guide Retrieved 25 October, 2013, from http://www.eifl.net/european-orphan-works-directive-eifl-guide

Ferri, D. (2008). The cultural constitution of the European Union [La costituzione culturale dell'Unione europea]. Padova: CEDAM.

Ferri, D. (2009). The prescriptive dimension of culture. A comparative analysis between signifier and signified [La dimensione prescrittiva della cultura. Un'analisi comparata tra significante e significato]. Fournal of Comparative Public Law and European Italian [Rivista di Diritto pubblico comparato italiano ed europeo].

Ferri, D. (forthcoming 2013). The UN Convention on the Rights of Persons with Disabilities as an "Integral Part" of EU Law EUI Working Papers: AEL 2013/10.

Gompel, S. v., \& Hugenholtz, P. B. (2010). The Orphan Works Problem: The Copyright Conundrum of Digitizing Large-Scale Audiovisual Archives, and How to Solve It. Popular Communication, 8(1), 61-71.

Halvorsen, R. (2009). The Accessibility Principle in the UN Convention on the Rights of Persons with Disabilities and Implication for EU Disability Law and Policy paper prepared for EFC UNCRPD Implementation Project (unpublished).

Hargreaves, I. (2011a). Digital opportunity a review of intellectual property and growth: an independent report / by Ian Hargreaves, from http://www.ipo.gov.uk/ipreview-finalreport.pdf

Hargreaves, I. (2011b). Digital Opportunity: A Review of Intellectual Property and Growth: independently produced report.

Hargreaves, I., \& Hugenholtz, B. (2013). Copyright Reform for Growth and Jobs: Lisbon Council Policy Brief: Lisbon Council.

Harnacke, C., \& Graumann, S. (2012). Core Principles of the UN Convention on the Rights of Persons with Disabilities: An Overview. In J. Anderson \& J. P. M. Philips (Eds.), Disability and universal human rights: legal, ethical, and conceptual implications of the Convention on the rights of persons with disabilities. Utrecht: Netherlands Institute of Human Rights.

Harpur, P. (2012). Embracing the New Disability Rights Paradigm: The Importance of the Convention on the Rights of Persons with Disabilities. Disability \& Society, 27(1), 1-14.

Hosking, D. (2013). Staying the Course: The European Disability Strategy 2010-2020. In L. Waddington, G. Quinn \& E. Flynn (Eds.), European yearbook of disability law. Volume 4, Intersentia.

IDATE. (2012). Cord-cutting: USA / Europe Benchmark - Is Europe ready? : Research and Markets.

Kayess, R., \& French, P. (2008). Out of Darkness into Light? Introducing the Convention on the Rights of Persons with Disabilities. Human Rights Law Review, 8(1), 1-34.

Koch, I. E. (2009). From Invisibility to Indivisibility: The International Convention on the Rights of Persons with Disabilities. In O. M. Arnardóttir \& G. Quinn (Eds.), The UN Convention on the Rights of Persons with Disabilities: European and Scandinavian perspectives. Leiden; Boston: Martinus Nijhoff.

Kongolo, T. (2012). Towards an International Legal Instrument on Exceptions and Limitations to Copyright for Visually Impaired Persons/Persons With Print Disabilities: Current International Negotiations. European Intellectual Property Review: A Monthly Review: A fournal Concerning the Management of Technology, Copyrights and Trade Names, 34(12), 823-833.

Kuzma, J. M. (2010). Accessibility design issues with UK e-government sites. Gov. Inf. Q. Government Information Quarterly, 27(2), 141-146.

Laaksonen, A. (2010). Making culture accessible: access, participation and cultural provision in the context of cultural rights in Europe. Strasbourg: Council of Europe Pub.

Lewinski, S. v. (2008). International copyright law and policy. Oxford: Oxford University Press. 
LIBER. (2013). "Licences for Europe - A Stakeholder Dialogue" text and data mining for scientific research purposes working group Retrieved 27 October, 2013, from http://www.libereurope.eu/news/licences-foreurope-a-stakeholder-dialogue-text-and-data-mining-for-scientific-research-purpose

Lord, J. E. (2010). Accessibility and Human Rights fusion in the CRPD: Assessing the scope and the content of the accessibility principle and duty under CRPD, Presentation for the General Day of Discussion on Accessibility. Paper presented at the Committee on the Rights of Persons with Disabilities. http://www. ohchr.org/EN/HRBodies/CRPD/Pages/DGD7102010.aspx

Mabbett, D. (2005). The Development of Rights-based Social Policy in the European Union: The Example of Disability Rights. Fournal of Common Market Studies, 43(1), 97-120.

Michailakis, D. (1999). The Standard Rules: A weak Instrument and A Strong Commitment. In M. Jones \& L. A. B. Marks (Eds.), Disability, divers-ability, and legal change. The Hague; Boston; Cambridge, MA: M. Nijhoff Publishers; sold and distributed in North, Central and South America by Kluwer Law International.

Moreno, L., Galvez, M. C., Ruiz, B., \& Martinez, P. (2008). Inclusion of Accessibility Requirements in the Design of Electronic Guides for Museums. Lecture Notes in Computer Science (5105), 1101-1108.

Muñoz Machado, S., \& Lorenzo, R. d. (1997). European disability law. Madrid: Escuela Libre Editorial.

N. Z. G. W. Toolkit. (2013). Web Accessibility Standard 1.0. Aukland, New Zealand: New Zealand Government Web Toolkit.

Oliver, M. (1996). Understanding disability: from theory to practice. New York: St. Martin's Press.

Pineschi, L. (2008). Convention on cultural diversity and the international law of human rights [Convenzione sulla diversità culturale e diritto internazionale dei diritti umani]. In L. Zagato (Ed.), Cultural identities in the latest tools UNESCO: a new approach to peace building? [Le identità culturali nei recenti strumenti Unesco: un approccio nuovo alla costruzione della pace?]. [Padova]: CEDAM.

Psychogiopoulou, E. (2008). The integration of cultural considerations in EU law and policies, from http:// public.eblib.com/EBLPublic/PublicView.do?ptiID=468337

Quinn, G. (2009a). Disability and Human Rights: a New Field in the United Nations. In C. Krause \& M. Scheinin (Eds.), International Protection of Human Rights: a Textbook. Turku/Abo: Abo Akademi University, Institute for Human Rights, Abo Akademi UIHR.

Quinn, G. (2009b). A Short Guide to the United Nations Convention on the Rights of Persons with Disabilities. In G. Quinn \& L. Waddington (Eds.), European yearbook of disability law. Volume. 1 Volume. 1. Antwerp; Oxford: Intersentia.

Rekas, A. (2013). Tracking the Progress of the Proposed WIPO Treaty on Exceptions and Limitations to Copyright to Benefit Persons with Print Disabilities. In L. Waddington, G. Quinn \& E. Flynn (Eds.), European yearbook of disability law. Volume 4, Intersentia.

Ritchie, H., \& Blanck, P. (2003). The Promise of the Internet for Disability: A Study of On-line Services and Web Site Accessibility at Centers for Independent Living. Behavioral Sciences \& the Law, 21, 5-26.

Sandler, L. A., \& Blanck, P. (2005). The quest to make accessibility a corporate article of faith at Microsoft: case study of corporate culture and human resource dimensions. Behavioral Sciences $\mathcal{E}$ the Law, 23(1), 39-64. doi: $10.1002 /$ bsl.625

Sar, E. V. D. (2013a). Game of Thrones Piracy "Better Than an Emmy," Time Warner CEO Says. Retrieved from http://torrentfreak.com/game-of-thrones-piracy-better-than-an-emmy-time-warner-ceo-says-130808/

Sar, E. V. D. (2013b). Piracy Doesn't Hurt Game of Thrones, Director Says. Retrieved from http:// torrentfreak.com/piracy-doesnt-hurt-game-of-thrones-director-says-130227/

Seatzu, F. (2008). The United Nations Convention on the Rights of Persons with Disabilities guaranteed rights, cooperation, control procedures [La Convenzione delle Nazioni Unite sui diritti delle persone disabili: diritti garantiti, cooperazione, procedure di controllo]. Human Rights and International Law [Diritti umani e diritto internazionale], 3(1), 259-280.

Smith, R. C. (2011a). Determining Regulatory Competence for Audiovisual Media Services in the European Union. Fournal of Media Law, 3(2), 263-285.

Smith, R. C. (2011b). The Evolution of Cultural Policy in the EU. In P. P. Craig \& G. De Búrca (Eds.), The Evolution of EU law. Oxford; New York: Oxford University Press.

Stamatopoulou, E. (2007). Cultural rights in international law: Article 27 of the Universal Declaration of Human Rights and beyond. Leiden; Boston: Martinus Nijhoff.

Stein, M. A., \& Lord, J. E. (2009). Future prospects for the United Nations Convention on Disability. In O. M. Arnardóttir \& G. Quinn (Eds.), The UN Convention on the Rights of Persons with Disabilities: European and Scandinavian perspectives. Leiden; Boston: Martinus Nijhoff.

Summer, R. (2011). The single digital market: a vision for Europe. Ericsson Business Review, (2), 53-54.

Thielman, S. (2013). Bewkes: Game of Thrones Piracy 'Better Than an Emmy' Exec talks streaming, stealing and the Time Inc. spinoff By Sam Thielman. Retrieved from http://www.adweek.com/news/television/ bewkes-game-thrones-piracy-better-emmy-151738

Traustadottir, R. (2009). Disability Studies, the Social Model and Legal Developments. In O. M. Arnardóttir \& G. Quinn (Eds.), The UN Convention on the Rights of Persons with Disabilities: European and Scandinavian perspectives. Leiden; Boston: Martinus Nijhoff. 
UN. (1992). World programme of action concerning disabled persons. Geneva: United Nations Department of Public Information.

UN. (1995). General Comment No. 5, Persons with disabilities (Eleventh session, 1994), U.N. Doc E/1995/

22 Retrieved 16 October, 2013, from http://www1.umn.edu/humanrts/gencomm/epcomm5e.htm

UN. (2007). From Exclusion to Equality - Realizing the Rights of Persons with Disabilities: Handbook for Parliamentarians on the Convention of the Rights of Persons with Disabilities and its Optional Protocol. Geneva: United Nations.

UN Committee on the Rights of Persons with Disabilities. (2013). Draft General Comment on Article 9 of the Convention.

UNESCO. (2006). Inclusive Education People with Disabilities Retrieved 16 October, 2013, from http:// www.unesco.org/new/en/education/themes/strengthening-education-systems/inclusive-education/peoplewith-disabilities/

US Department of Justice. Nondiscrimination on the Basis of Disability: Accessibility of Web Information and Services of State and Local Governments, 75 FR 43460C.F.R. (2012).

Waddington, L. (1999). The European Community's Response to Disability. In M. Jones \& L. A. B. Marks (Eds.), Disability, divers-ability, and legal change. The Hague; Boston; Cambridge, MA: M. Nijhoff Publishers; sold and distributed in North, Central and South America by Kluwer Law International.

Waddington, L. (2006). From Rome to Nice in a wheelchair: the development of a European disability policy. Groningen: Europa Law Publishing.

Zagato, L. (2010). State aid for culture: recent developments? [Aiuti di Stato alla cultura: recenti sviluppi?]. In L. S. Rossi \& E. Baroncini (Eds.), Relationships between legal and individual rights: studies of the students in honor of Mengozzi [Rapporti tra ordinamenti e diritti dei singoli: studi degli allievi in onore di Paolo Mengozzi]. Napoli: Editoriale scientifica.

\section{EU Legislation and Soft Law}

Directive 1999/5/EC of the European Parliament and of the Council of 9 March 1999 on radio equipment and telecommunications terminal equipment and the mutual recognition of their conformity [1999] OJ L91/10

Directive 2001/29/EC of the European Parliament and of the Council of 22 May 2001 on the harmonisation of certain aspects of copyright and related rights in the information society [2001] OJ

Directive 2002/21/EC of the European Parliament and of the Council of 7 March 2002 on a common regulatory framework for electronic communications networks and services (Framework Directive) [2002] OJ L 45/33

Council Regulation (EC, Euratom) No 1700/2003 of 22 September 2003 amending Regulation (EEC, Euratom) No 354/83 concerning the opening to the public of the historical archives of the European Economic Community and the European Atomic Energy Community [2003] OJ L46/1

Directive 2009/136/EC of the European Parliament and of the Council of 25 November 2009 amending Directive 2002/22/EC on universal service and users' rights relating to electronic communications networks and services, Directive 2002/58/EC concerning the processing of personal data and the protection of privacy in the electronic communications sector and Regulation (EC) No 2006/2004 on cooperation between national authorities responsible for the enforcement of consumer protection laws [2009] OJ L337/11.

Directive 2009/140/EC of the European Parliament and of the Council of 25 November 2009 amending Directives 2002/21/EC on a common regulatory framework for electronic communications networks and services, 2002/19/EC on access to, and interconnection of, electronic communications networks and associated facilities, and 2002/20/EC on the authorisation of electronic communications networks and services [2009] OJ L337/37

Regulation (EC) No 1211/2009 of the European Parliament and of the Council of 25 November 2009 establishing the Body of European Regulators for Electronic Communications (BEREC) and the Office [2009] OJ L337/1

Council Decision 2010/48/EC of 26 November 2009 concerning the conclusion, by the European Community, of the United Nations Convention on the Rights of Persons with Disabilities [2010] OJ L23/35

Directive 2010/13/EU of the European Parliament and of the Council of 10 March 2010 on the coordination of certain provisions laid down by law, regulation or administrative action in Member States concerning the provision of audiovisual media services (Audiovisual Media Services Directive) [2010] OJ L95/1

Directive 2012/28/EU of the European Parliament and of the Council of 25 October 2012 on certain permitted uses of orphan works [2012] OJ L299/5

Report from the Commission on the application of Council Recommendation 86/379/EEC of 24 July 1986 on the employment of disabled people in the community. Brussels; Luxembourg: Office for Official Publications of the European Communities 
Communication from the Commission on Equality of Opportunity for People with Disabilities and Draft Resolution of the Council and of Representatives of the Governments of the Member States Meeting Within the Council on Equality of Opportunity for People with Disabilities, COM (96) 406 final [1996].

Communication from the Commission on Equal opportunities for people with disabilities: a European action plan $\operatorname{COM(2003)~} 650$ final

Communication from the Commission European Disability Strategy 2010-2020: A Renewed Commitment to a Barrier-Free Europe COM(2010a) 636 final

Communication from the Commission to the European Parliament, the Council, the European Economic and Social Committee and the Committee of the Regions on a European agenda for culture in a globalizing world $\operatorname{COM}(2007) 242$ final

Communication from the Commission to the European Parliament, the Council, the European Economic and Social Committee and the Committee of the Regions. Europe 2020 flagship initiative innovation union, $\operatorname{SEC}(2010 \mathrm{~b}) 1161$

Communication from the Commission A Digital Agenda for Europe COM(2010) 245 final Green paper. Copyright in the knowledge economy, $\operatorname{COM}(2008) 466 / 3$

Council conclusions of 10 May 2012 on the digitisation and online accessibility of cultural material and digital preservation [2012] OJ $C 169 / 5$

Conclusions of the Council and of the Representatives of the Governments of the Member States, meeting within the Council, on the Work Plan for Culture 2011-2014 [2010] OJ C 325/01

Executive summary of the Opinion of the European Data Protection Supervisor on the Commission proposal for a Council regulation amending Regulation (EEC, Euratom) No 354/83, as regards the deposit of the historical archives of the institutions at the European University Institute in Florence [2013] OJ C 28/05

\section{International Treaties and Soft Law}

UN. (1967). International Covenant on Economic, Social and Cultural Rights and International Covenant on Civil and Political Rights with Optional Protocol. Adopted by the General Assembly of the United Nations and opened for signature at New York on $16 \mathrm{dec}$. 1966. Pres. to Parliament by the Secr. of State for Foreign Affairs by comm. of Her Majesty March 1967. London: H. M. S. O.

UN. (1988). Universal Declaration of Human Rights. [New York]: UN Department of Public Information.

UN. (2006). Convention on the Rights of Persons with Disabilities and Optional protocol.

UNESCO. (2002). Unesco universal declaration on cultural diversity: a vision, a conceptual platform, a pool of ideas for implementation, a new paradigm. Paris, France: Unesco.

UNESCO. (2005). Convention on the protection and promotion of the diversity of cultural expressions. Paris: UNESCO.

WIPO. (2010). Draft Joint Recommendation concerning the improved access to works protected by copyright for persons with a print disability: Proposal by the Delegation of the European Union.

WIPO. (2013). Marrakesh Treaty to Facilitate Access to Published Works by Visually Impaired Persons and Persons with Print Disabilities. [S.1.]: Stationery Office Ltd.

\section{Case Law}

Case C-78/70 Deutsche Grammophon v Metro, Judgement of June 8, 1971, (1971) European Court Reports, 487.

Case C-531/07 Fachverband der Buch- und Medienwirtschaft v. LIBRO, Judgement of April 30, 2009 (2009) European Court Reports, I-3717. 